\title{
The pips are squeaking
}

\author{
David Payne digital editor
}

The BMJ

Last week Mark Carney, governor of the Bank of England, announced a historic cut in the bank interest rate to $0.25 \%$ as part of a package of measures to help boost the United Kingdom's economy in the wake of the referendum result in favour of leaving the European Union.

As the Health Foundation's chief executive, Jennifer Dixon, and colleague Will Warburton warn this week (doi:10.1136/ bmj.i4204), uncertainty after the EU referendum threatens the stability of the UK economy and poses a real threat to NHS funding. The NHS gets $£ 1$ of every $£ 5$ of taxes paid in the UK. Prospects for extra cash look bleak, they argue. The "reset" for financial performance (doi:10.1136/bmj.i4360), announced by NHS England and NHS Improvement on 21 July, signals that money is indeed too tight to mention, things will only get tougher, and staff should expect demands for greater productivity and efficiency.

Wasn't a vote in favour of Brexit meant to save the NHS? Vote Leave's pre-referendum broadcast suggesting that the service could benefit from an extra $£ 350 \mathrm{~m}(€ 410 \mathrm{~m} ; \$ 460 \mathrm{~m})$ a week if the UK left the EU is unpicked by Meg Carter (doi:10.1136/ bmj.i4342). The ad agency boss Jon Sharpe fears that public confidence in all official statistics could diminish as a result of the broadcast and could threaten effective campaigning on public health in the future. Pressure is growing for an independent regulator to govern political advertising.

In this time of economic uncertainty, what does the future hold for pay for performance schemes such as the Quality and
Outcomes Framework? Martin Roland and Bruce Guthrie (doi:10.1136/bmj.i4060) examine QOF's successes and failures in raising the quality of care since its introduction in 2004-a time when morale in general practice was low and pay had fallen behind that of specialists.

Scotland is now abandoning QOF in favour of an alternative quality improvement programme (doi:10.1136/bmj.i1763). Implementation has diverged across other UK regions and countries as GPs struggle with the administrative burden it imposes. Nicholas Steel and Paul Shekelle maintain that a transformed QOF is an important tool in the drive to deliver care that is truly patient centred (doi:10.1136/bmj.i4103), while Martin Roland and Frede Olesen explore what other countries can learn from the UK's experience (doi:10.1136/bmj.i4058).

Let's end with a success story. In December last year we investigated why Dutch GPs were so much happier than their UK colleagues (doi:10.1136/bmj.h6870). Now Tony Sheldon describes how the country slashed its use of antibiotics in agriculture as well as healthcare (doi:10.1136/bmj.i4192).

And finally, if you're in Edinburgh this month go and see our award winning columnist Margaret McCartney. The Glasgow GP is not there to play Pokémon Go (doi:10.1136/bmj.i4306) but is making her Fringe Festival debut alongside the medical satirist Phil Hammond (doi:10.1136/bmj.i4378). See my blog post for other medicine related events at the Edinburgh Festival: bmj.co/edinburgh2016. 